NBER WORKING PAPER SERIES

\title{
THE USE AND MEANING OF WORDS IN CENTRAL BANKING: INFLATION TARGETING, CREDIBILITY, AND TRANSPARENCY
}

\author{
Benjamin M. Friedman \\ Working Paper 8972 \\ http://www.nber.org/papers/w8972 \\ NATIONAL BUREAU OF ECONOMIC RESEARCH \\ 1050 Massachusetts Avenue \\ Cambridge, MA 02138 \\ June 2002
}

The views expressed herein are those of the author and not necessarily those of the National Bureau of Economic Research.

(C) 2002 by Benjamin M. Friedman. All rights reserved. Short sections of text, not to exceed two paragraphs, may be quoted without explicit permission provided that full credit, including (C) notice, is given to the source. 
The Use and Meaning of Words in Central Banking:

Inflation Targeting, Credibility, and Transparency

Benjamin M. Friedman

NBER Working Paper No. 8972

June 2002

JEL No. E52

\begin{abstract}
Inflation targeting offers the promise of introducing to monetary policy a logic and consistency that some central banks' deliberations sorely missed in the past. At least in today's inherited monetary policymaking context, however, inflation targeting also serves two further objectives that are of more questionable import, and while seemingly contradictory, the two are ultimately related: By forcing participants in the monetary policy debate to conduct the discussion in a vocabulary pertaining solely to inflation, inflation targeting fosters over time the atrophication of concerns for real outcomes. In the meanwhile, inflation targeting hides from public view whatever concerns for real outcomes policymakers do maintain. Both objectives are understandable. Whether either is desirable on economic grounds is an open question. Neither is very consistent with the role of monetary policy in a democracy.
\end{abstract}

\author{
Benjamin M. Friedman \\ Department of Economics \\ Harvard University \\ Littauer Center 127 \\ Cambridge, MA 02138 \\ and NBER \\ bfriedman@harvard.edu
}


Revised

January, 2002

\title{
THE USE AND MEANING OF WORDS IN CENTRAL BANKING: INFLATION TARGETING, CREDIBILITY, AND TRANSPARENCY
}

\author{
Benjamin M. Friedman* \\ William Joseph Maier Professor of Political Economy \\ Harvard University
}

Charles Goodhart is the Samuel Johnson of monetary policy. Few people in the field have written more. Few have written in more genres: in Goodhart's case, scholarly research papers expanding the frontier of the subject; practical analyses illuminating the policy problems of the day; memoranda, including many never published, for circulation within the central bank; even textbooks for educating future generations of economists and central bankers. Few people have written works of greater quality, or with greater effect on how one's readers think and act. And like Johnson (or so the historical accounts tell us), Charles Goodhart exhibits — how to put the matter delicately? - a plethora of personal eccentricities that are as endearing to his countless friends as they must be baffling to anyone who merely observes him at a distance.

Goodhart's career spans an extraordinary period of development in both the thinking and the practice of monetary policy. Notwithstanding the many false starts in both thinking and

*This paper was written for the Conference in Honour of Charles Goodhart, Bank of England, London, November 15-16, 2001. I am grateful for research support from the Harvard Program for Financial Research. 
practice — and there have been many - few informed persons would doubt that both are in far better condition today than they were four decades ago. Especially with respect to the making of actual monetary policy, and especially in a volume like this one, a certain amount of selfcongratulation would certainly be in order. But problems remain nonetheless, including problems stemming directly from the most recent series of advances. As the late Christopher Lasch observed, "The advance of the intellect is highly desirable, but it will not go very far if it looks constantly backward to admire the distance already traveled." The object of this paper is therefore to point to a part of the monetary policymaking glass that yet remains empty, and to speculate about what central bankers might do to fill it.

Perhaps oddly for an aspect of economic policy that involves actually doing something buying or selling securities in the open market, making advances to banks, and so on — many of the problems at the center of monetary policymaking today concern the use of words. Samuel Johnson was sufficiently taken with the importance of using words correctly that he spent seven years producing the first modern dictionary of the English language. Two centuries later another Englishman, Eric Blair (a.k.a. George Orwell), highlighted the threat to democratic society posed by governmental institutions that use words to mean whatever it suits their purposes to have them mean. Neither evidently thought much in particular about monetary policy. But as so much of the new research in the field during the last few decades has rightly emphasized, monetary policy too is partly a matter of communication. And here too, it is important to use words to mean what they are properly supposed to mean, even if it might suit the convenience of the central bank to have them mean something else. 
What Does Inflation Targeting Mean?

One of the most significant developments in the theory and practice of monetary policy in recent years has been inflation targeting. The Bank of England is but one of an increasing number of central banks that have adopted explicit inflation targeting as the conceptual framework within which they formulate their monetary policy decisions and communicate those decisions to financial market participants, firms and households more generally, other government decision makers, and ultimately the world at large. But what exactly does inflation targeting mean?

As Mervyn King (1997) among others has usefully emphasized, inflation targeting need not mean that the sole objective guiding monetary policy is to achieve a specified rate of price inflation. (King colorfully describes advocates of such a policy "inflation nutters.") In principle, an inflation-targeting regime is consistent not only with directing monetary policy toward real objectives like output and employment but, indeed, with giving priority (although not absolute priority) to such matters over concerns about the rise or fall of prices and wages. But in that case, why put the matter in terms of an inflation target?

The rationale for inflation targeting emerges as the joint consequence of two lines of thought within the economics of monetary policy. First, because the central bank in effect has only one instrument at its disposal — it can be either open market operations or the interest rate the bank charges on advances — the standard Tinbergen-Theil logic implies that it is possible to express the policy chosen at any time in terms of the intended outcome (or, in a dynamic setting, the intended trajectory) of any single economic magnitude that monetary policy affects: 
inflation, output, employment, the economy's foreign balance, even some magnitude of no intrinsic importance whatsoever (the obvious example is the level or growth rate of some measure of "money").

But, then, why choose inflation? The second line of thought within the field that underlies the concept of inflation targeting is the Phelps-Friedman "natural rate" model of aggregate supply in the market for goods and services. Under most familiar versions of the natural rate model, a trade-off exists between real outcomes like output and employment and nominal outcomes like prices and inflation — and, moreover, a trade-off that the central bank can exploit — but only over some finite (and presumably fairly short) horizon. By contrast, in the long run there is no such trade-off, or at least not one subject to exploitation by monetary policy. Long-run real outcomes depend on such real factors as endowments, preferences and technologies. In the long run only nominal magnitudes are subject to monetary influences. The conceptual appeal of inflation targeting, therefore, is to express the objective of monetary policy not in terms of the intended trajectory for just any randomly selected variable, as the TinbergenTheil logic would permit, but in terms of the trajectory for a variable that monetary policy can presumably affect in the long as well as the short run.

In fact, the evidence for the natural rate model has never been as strong as the prevailing consensus within the economics profession (not to mention the case for inflation targeting) has let on. As Robert Solow has argued, the natural rate model seems a good description of the U.S. experience in the post World War II period, but only that — and in particular, not of the European post-war experience, nor of either the U.S. or the European experience before the war. Theoretical work (by Blanchard and Summers, for example) has shown numerous ways in which 
some part of what the natural rate model takes to be purely temporary departures of output, employment or unemployment from the equilibrium level induce permanent, or at least very long-lasting, changes in the equilibrium itself. Empirical work based on fairly long time periods indicates that the evidence for a negatively sloped Phillips curve (King and Watson), or for a positive link between inflation and the economy's investment rate (Ahmed and Rogers), is at least as strong as the evidence for long-run neutrality. But the evidence is hardly conclusive on either side, and for the moment the logic of the natural rate model underlies much of the structure of modern macroeconomics. The logic behind inflation targeting is consistent with that whole.

Even so, as King has emphasized, the important point about inflation targeting is that expressing the intended policy outcome in terms of the trajectory for any one variable does not imply that the central bank is indifferent with respect to outcomes for all other variables. The point is most explicit in the inflation targeting framework suggested by Lars Svennson, in which the central bank targets its own forecast of future inflation as if that forecast were a classical intermediate target variable such as money. ${ }^{1}$

In Svennson's formulation, the central bank at each point in time seeks to make its forecast of future inflation follow a specific trajectory. If some economic disturbance or policy error has resulted in an inflation rate different from whatever rate the central bank is seeking to achieve, and if inflation is the only variable about which the central bank is not indifferent, then

${ }^{1}$ Because of the relation between a future outcome and its expectation, however, this particular form of intermediate targeting is not subject to the standard criticisms of the use of money or other such variables as intermediate targets. Moreover, by targeting its own forecast, rather than that of private-sector forecasters, the central bank can avoid potential dynamic instabilities of the kind identified by Woodford, although there is an obvious sacrifice of the efficacy of external monitoring of policy performance. 
the optimal trajectory simply involves returning to the desired inflation rate instantly — or more practically, in the presence of lags, as soon as is at all possible. If other variables like output or employment (or even the level or change of interest rates) matter too, the optimal trajectory following a disturbance or a policy error then involves bringing the forecast of future inflation into line with the unconditionally desired inflation rate only over some longer period of time.

Not surprisingly, the length of the interval over which the forecast of future inflation optimally returns to the unconditionally desired rate in this formulation — or, equivalently, the optimal speed of convergence if it is conceived as asymptotic — depends on the strength of the central bank's preferences with respect to inflation vis-a-vis its other objectives. For a given short-run cost of disinflation in terms of output and employment, the stronger is the preference for being at the unconditionally desired inflation rate, the faster the optimal inflation forecast trajectory returns to it. Conversely, the stronger is the preference for being at equilibrium output and employment, the more slowly the optimal inflation forecast trajectory returns to the unconditionally desired rate. (Similarly, for given preferences, the smaller is the short-run cost of disinflation, the faster the optimal trajectory returns to the unconditionally desired inflation rate, and vice versa.) Hence not only does inflation forecast targeting not necessarily mean that the central bank is an "inflation nutter," but there is an explicit way in which its preferences with respect to real outcomes can enter the inflation targeting framework.

\section{Do Central Banks Target Real Outcomes? Should They?}

It is a familiar characteristic of policy debate, and probably of intellectual discourse more generally, that the language in which that debate takes place exerts a powerful influence over the 
substance of what the participants say, and eventually even over what they think. As David Hume remarked about one of the central political debates of his day, "The Tories have been obliged for so long to talk in the republican stile, that they ... have at length embraced the sentiments, as well as the language of their adversaries." Notwithstanding the compatibility in principle of inflation targeting as a conceptual framework for implementing a monetary policy in which real outcomes matter as well as inflation, an observer who has paid attention to the last quarter century of debate about monetary policy is entitled to suspect that a powerful motivation for adopting this framework, at least in some quarters, is the hope that if the explicit discussion of the central bank's policy is carried out entirely in terms of an optimal inflation trajectory, concerns for real outcomes may somehow atrophy or even disappear from consideration altogether.

One of the most striking developments in monetary economics during this last quarter century has been the renewed attempt to banish from the purview of monetary policymaking any sense of responsibility for real outcomes. This is in fact an old debate, with familiar antecedents in central banks' response to the depression of the 1930s and well before that. Although there is no necessary link, there is ground for thinking that inflation targeting may in practice be yet the latest incarnation of this effort.

One reason for suspecting that this is so is the reluctance, within today's central banking community, to acknowledge openly an interest in or concern for real outcomes. For example, the charter of the European Central Bank either does or does not charge the bank to be responsible for such matters depending upon how one reads the relationship of Article 103 to Article 102a, and of Article 102a and Article 105 to Article 2, in the Maastricht Treaty. Because few people 
either have read or ever will read these formal statements — and, even more so, because their language defies plain meaning for anyone who tries — the issue defies resolution. The ECB, of course, has not adopted inflation targeting (at least not formally). But among central banks that have done so, often the articulation of what that inflation targeting strategy means is devoid of any explicit reference to real outcomes.

One frequently stated rationale for eschewing concern for real outcomes is the proposition that there is nothing the central bank can usefully do to affect them anyway: in effect, the neutrality of the natural rate model holds in the short as well as the long run. ${ }^{2}$ As Ernst Welteke, president of the Deutsche Bundesbank and therefore a member of the ECB's governing council, recently stated the argument, "The ECB doesn't have the job of steering the economy. The best contribution monetary policy can make to growth and employment is to keep prices stable." Today this idea is familiar from many sources, including central banks (and central bankers) other than the ECB: Maintaining price stability fosters greater output and employment in the long run. And in the short run there is nothing monetary policy can do about either output or employment anyway. ${ }^{3}$

${ }^{2}$ Alternatively, even if monetary policy is not neutral with respect to real outcomes in the short run, the familiar problems of uncertainty and lagged effects are sufficiently severe that attempting to exploit this short-run nonneutrality is as likely to do harm as good.

${ }^{3}$ Similar views are familiar in the U.S. as well. For example, as Alfred Broaddus, president of the Federal Reserve Bank of Richmond, recently argued, "both theory and evidence indicate that the Fed cannot control real variables directly with monetary policy, and in my view there are reasonable grounds to presume that the Fed will optimize its contribution to the economy's overall performance by maintaining credibility for low inflation [here Mr. Broaddus cites Goodfriend and King]. A unitary goal focused on low inflation would strengthen credibility by making the Fed's commitment to this objective definite and unambiguous." 
The most immediate problem with such a point of view is that even if inflation were the only aspect of economic activity that the central bank sought to affect, it is unclear how it would go about doing so without in the first instance deliberately influencing the pace of real activity. In an earlier era some economists believed that simply keeping the quantity of money, however measured, in step with some predetermined growth path would lead to a corresponding inflation path for prices. But the collapse of empirical relationships between money and prices in many countries roughly twenty years ago has mostly removed this idea from the realm of practical monetary policymaking (although money certainly can be, and often still is, used as an information variable to help predict future inflation and so on). Instead, the conceptual route to keeping inflation on target lies through the short-term aggregate supply curve. For practical purposes, targeting inflation means in the first instance targeting output - not because output necessarily matters for its own sake, but because output in relation to some capacity benchmark is what matters for inflation. ${ }^{4}$

But once the point is accepted that monetary policy does systematically affect real outcomes in the short run — indeed, so much so that this is the key to its influence over price inflation — the rationale that the central bank should not seek to affect real outcomes because it cannot becomes vacuous. It is then necessary to address the issue on its merits. The monetary economics literature provides no such argument, however. The most familiar line of thinking on the issue in the literature of the past two decades has been the argument, based on time

${ }^{4}$ For example, the fact that a central bank's monetary policy actions approximately follow a "Taylor rule," with a significant role for the usual output or unemployment term in determining its chosen short-term interest rate, need not imply that the central bank is concerned with real outcomes for their own sake. Output or unemployment may be present in the central bank's reaction function merely as a source of information about future inflation. 
inconsistency, that the wrong kind of concern for real outcomes can lead in the long run (and, depending on expectations, perhaps in the short run as well) to an undesirable rate of inflation with little (in the limit, no) gain in real terms anyway. But the fact that the wrong kind of concern for real outcomes can have these undesirable consequences does not constitute a generic case against treating output or employment as proper objectives of monetary policy at all.

Nonetheless, the call for monetary policy to adopt an exclusive focus on prices to the exclusion of real outcomes has been widespread throughout this period. In Japan, for example, Yasuo Matsushita, at the time Governor of the Bank of Japan, argued that "Most people agree that the objective of monetary policy is the maintenance of price stability.... The maintenance of price stability does not conflict with the achievement of stable economic growth and employment conditions. For example, measures to prevent overheating (or recession) of the economy can at the same time contain inflation (or avoid deflation), and provide medium- to long-run price stability; and this price stability in turn, is a prerequisite for achieving sustainable growth of the economy."

In the United States, a few years ago the chairman of the Joint Economic Committee of the Congress introduced legislation to repeal the reference to "maximum employment" in the Federal Reserve System's existing mandate, and to charge U.S. monetary policymakers, except for an initial transition period, simply to "maintain a monetary policy that effectively promotes price stability." Although in the end Congress did not pass the bill, numerous senators co-

\footnotetext{
${ }^{5}$ Governor Matsushita's remarks clearly admit only the possibility of disturbances to aggregate demand, which influence output and prices in the same direction. As much of the academic literature of optimal monetary policy has emphasized, the more interesting problem arises in the case of disturbances to aggregate supply, which normally influence output and prices in opposite directions. (For a concise review, see Clarida et al. (1999).)
} 
sponsored it including the then-majority leader, Bob Dole (and his successor, Trent Lott).

Another U.S. example is the unfortunate experience of the then-vice chairman of the Federal Reserve, Alan Blinder, who found himself subject to overwhelming criticism from both central banking and private financial circles for saying explicitly that U.S. monetary policy should focus on both inflation and employment — as, indeed, the law requires. (Prevailing legislation charges the Federal Reserve to conduct monetary policy "so as to promote effectively the goals of maximum employment [and] stable prices," among other objectives.)

Not surprisingly, outside academic circles most of the talk of banishing real outcomes from the purview of monetary policy took place during an era of sustained economic growth. ${ }^{6}$ When business is expanding and profits are strong and jobs are plentiful (even in chronically high-unemployment European countries), it is easy to say that inflation is all that should matter. More recently, now that economies are slowing, talk of ignoring real outcomes in favor of a sole focus on price stability has begun to disappear.

Here again the U.S. experience can serve as a useful example: No one pretended that the five rounds of easing that the Federal Reserve instituted in 2001 before the atrocities of September 11 were necessary to prevent inflation from falling too low. Consumer prices in 2000 rose by $3.4 \%$, up from $2.7 \%$ increase the year before and just $1.6 \%$ the year before that. Excluding food and energy, U.S. consumer prices rose by $2.6 \%$ in 2000 , compared to $1.9 \%$ the year before. As of August 2001, the twelve-month increase was 2.7\%. No one argued in public

${ }^{6}$ Even the remarks by Governor Matsushita quoted above date from 1996, when the Japanese economy was enjoying a recovery (which in retrospect turned out to be short-lived). Earlier in the same speech, Mr. Matsushita stated that "the risk of a deflationary spiral, which was an issue of concern last year, has been practically eliminated." 
discourse that this was too little. (Other inflation measures, including most measures of wage inflation, had likewise either moved higher or at best remained unchanged.) Instead, everyone recognized that the purpose of the Federal Reserve's easier policy was to spur nonfinancial economic activity, or at least to prevent further slowing. Yet in central banking circles, open acknowledgment of responsibility for preventing an economic slowdown - except when too low a rate of output might threaten too low a rate of inflation — remains mostly unacceptable.

\section{What Does Transparency Mean?}

The meaning attached to ordinary words in any specific context often depends on the prior evolution of how that word has been used in that context. As a result, a listener or reader not sufficiently sensitive to this prior evolution may wonder why the word is now used as it is, or may even fail to understand the current meaning altogether. Monetary economics is no exception.

One familiar example is the theory of "real business cycles." One might suppose from the label that the idea is to emphasize the role of any of a variety of real phenomena, as opposed to monetary influences (including monetary policy in particular), in accounting for observed business fluctuations. But in the literature of monetary economics today, "real business cycle theory" means something even more specific — namely, a focus on factors affecting aggregate supply (technologies, willingness to work, etc.), as opposed to factors affecting aggregate demand (consumer sentiments, "animal spirits of entrepreneurs," etc.), in causing business fluctuations. The explanation is that real business cycle theory came into the field in the wake of a long-standing debate that, at least at the time, seemed to point to the primacy of monetary 
factors over real aggregate demand factors as the source of aggregate fluctuations. With real demand-side factors thus out of consideration, arguing that business fluctuations were due to real rather than monetary factors then implicitly made them a supply-driven phenomenon.

An example that moves closer to monetary policy is central bank independence. In much of the literature of this subject, "independence" means largely what an ordinary speaker of the language might well suppose: the ability, on institutional as well as practical grounds, of central bank policymakers to take the decisions they think best, without either prior or subsequent interference from other authority. ${ }^{7}$ But in parts of the literature, "independence" instead refers to the strength of the central bank's preferences with respect to inflation vis-a-vis real outcomes. For example, the widely read paper by Guy Debelle and Stanley Fisher, "How Independent Should a Central Bank Be?", primarily addresses the question of how much weight a central bank should place on its inflation objective compared to its objectives for real outcomes. In the formal model that represents the core of the paper's analysis, "central bank independence" is simply "defined as the central bank's aversion to inflation." As a result, "the inflation rate is clearly zero when the central bank is fully independent."

How did this usage arise? Again the answer lies in the prior evolution of context. The literature of central bank independence developed in the wake of the literature of time inconsistency, according to which the explanation for the high and chronic inflation that then plagued so many industrialized economies around the world was a systematic attempt by central bankers to "trick" private-sector decision makers into producing more by bringing about a higher

\footnotetext{
${ }^{7}$ The literature has also usefully distinguished between such independence with respect to "goals" versus "instruments" of monetary policy.
} 
inflation rate than they were expecting. But why would central bankers do such a foolish (and, according to the literature, ultimately unsuccessful) thing? Surely, left to their own devices they would not. Only the pressure of higher political authority to which they were subject could explain such blatant folly. Hence a central bank that was completely independent in the conventional sense would presumably exhibit no concern for real outcomes whatever - which is the meaning then attached to "independence" in this strand of the literature.

Today a major theme in the discussion and practice of monetary policy, closely connected to the strategy of inflation targeting, is "transparency." Again quoting Mervyn King (2000), "It is truly remarkable how much has changed over the past decade. The mystery and mystique has given way to transparency and openness. ... It is difficult to listen to a speech on domestic or international financial policy these days, without hearing about transparency. ... The communication of policymakers' intentions with a view to enhancing their credibility has come to play a central role in monetary policy."

As ample discussion in the literature also makes clear, considerations of communication, including in particular the quest for credibility and transparency, have also been a central motivation for inflation targeting. Congressional attempts at clarification notwithstanding, it is difficult for the public to know what "maximum employment" and "price stability" mean in the Federal Reserve's official mandate, much less to figure out how U.S. central bankers weight these two objectives over the short and medium run. By contrast, saying that the Bank of England's objective is to achieve inflation of $21 / 2 \%$ per annum, with departures above and below to be treated as equally undesirable, has a certain ready clarity. Nor is the matter limited to conveying in advance the central bank's intentions. In the absence of sharp definitions of the 
Federal Reserve's objectives, or of the relative weighting between them, neither the Congress (which under the U.S. Constitution has direct responsibility for monetary policy) nor any other element of the body politic can readily evaluate the central bank's performance after the fact. By contrast, judging how closely the Bank of England has met its inflation target is straight forward (although assessing blame is not).

But the emphasis on transparency and credibility did not emerge in a vacuum either, and the context in which these concepts came to the fore of the discussion of monetary policy in recent decades suggests that these words too may not bear entirely conventional meanings. In both cases the relevant context was in the first instance the time inconsistency literature, and more broadly the theory of the forward-looking aggregate supply curve.

The standard forward-looking aggregate supply curve that is the workhorse of so much of today's monetary economics literature expresses current inflation as a positive function of (1) the level of output supplied in relation to some benchmark equilibrium, (2) a shock to production costs or sellers' mark-ups, and (3) price-setters' expectations of future inflation. ${ }^{8}$ All else equal, therefore, lower inflation expected for the future means lower inflation today. Similarly, the lower is expected future inflation, the higher today's output can be in relation to equilibrium output without resulting in higher inflation today. On both counts (which are really just two ways of expressing the same relationship), as long as the central bank has preferences with respect to real output as well as inflation, it is beneficial to have private-sector decision makers expect that inflation will be low in the future.

${ }^{8}$ As Roberts has conveniently shown, a relationship of this generic kind can emerge as a result of random timing of price increases as in Calvo's model, nominal wage contracts as in Taylor's model, or convex costs of price adjustment as in Rotemberg's model. 
But as the experience of the 1970s harshly demonstrated, merely claiming that inflation will be low in the future is not sufficient to induce the public to expect that this will be so. Indeed, the original point of the time inconsistency argument was that even if policymakers are entirely sincere in their intentions to deliver on such a pledge — and even in the absence of surprise shocks - under some circumstances there is good reason for private-sector decision makers to believe that inflation will be high anyway: the low-inflation pledge will not be "credible."

In the wake of the evolution of this literature, a "credible" central bank therefore means something more than just a central bank that can be believed to follow through on its declared policy, whatever that policy may be. Specifically, in today's context a "credible" central bank is one that is believed to be firmly committed to low inflation. And in parallel, a "transparent" policy means one that the public understands to be "credibly" committed to low inflation.

Seen in this light, the connection to inflation targeting becomes (in the dictionary sense) transparent. Inflation targeting is a way of manipulating private-sector decision makers' expectations about future inflation. It puts before them the central bank's long-run objective of achieving inflation equal to such-and-such a rate. It removes from explicit discussion whatever objectives the central bank may hold for output, employment, or other real outcomes, over less than the long run. It likewise removes from discussion the trade-off that monetary policymakers perceive between inflation and real outcomes over less than the long run. It achieves "credibility," in the specific sense of making a commitment to low inflation believable, by keeping out of the discussion those considerations that would reveal that commitment to be 
qualified, and hence not completely credible in the usual sense. ${ }^{9}$ It is "transparent" in that it holds a part of what the central bank is doing before clear glass while obscuring other parts behind a logical partition.

The point is perhaps easiest to see in Svennson's framework of inflation forecast targeting. Few if any central banks that have adopted an inflation targeting strategy seek, or even say they seek, to return inflation to the unconditionally desired rate immediately (or, in the presence of lags, as immediately as is possible) after a supply shock or a policy error has resulted in some different rate. The reason is that doing so would unduly push real economic activity away from equilibrium.

To recall, the optimal speed of return is a direct expression of the relative weight placed on inflation vis-a-vis real outcomes. But while it is not uncommon for inflation targeting central banks to be open about the time horizon for returning to the unconditionally desired inflation rate (typically two years or more), few are explicit about the underpinnings from which, as Svennson shows, this optimal horizon arises: the level of output or employment that policymakers regard as desirable over this horizon, or, even more so, the weight, compared to that on inflation, that

${ }^{9}$ The opportunity for the central bank to affect the credibility of its policy in this way via its communcations strategy — is absent in the standard literature of time consistency. The reason is that this line of analysis usually assigns to private-sector decision makers full knowledge of the relevant parameters (including parameters describing policymakers' preferences, the slope of the short-run aggregate supply curve, and so on), so that a policy either is or is not "credible" depending upon whether it is or is not time consistent. But when the public lacks this knowledge, it is possible that communications by the central bank may affect private-sector perceptions, including perceptions about these key parameters, and hence may affect whether or not the public sees any given policy as time consistent and therefore "credible." 
they place on such objectives. "Transparency" is one-dimensional. It is so in order to achieve "credibility."

An analogous reluctance also appears in contexts other than strict inflation targeting. The $\mathrm{ECB}$, for example, consistently defines the price stability that its charter enjoins it to achieve as "a rate of price increase less than $2 \frac{1}{2} \%$ per annum." But does, say, an inflation of minus $1 \%$ (in other words, deflation) qualify as less than $2 \frac{1}{2} \%$ ? No, when pressed ECB officials explain that the phrase "a rate of price increase" implicitly rules out negative inflation. But for formal purposes the Bank does not use language that makes explicit the idea that any rate of inflation can be too low. In this example, "transparency" is not one-dimensional but one-sided. But here as well, the point of the asymmetry is to foster "credibility."

\section{Concluding Remarks}

The theory and practice of monetary policy have advanced enormously over the past few decades, and as of the beginning of the twenty-first century inflation targeting has emerged as one of the most salient new developments on both the theoretical and the practical fronts. Taken at face value, this framework holds out the prospect of resolving some of the internal contradictions that have thwarted central banks' efforts to achieve widely recognized macroeconomic goals in the past. It also offers the promise of introducing a logic and consistency that some central banks' deliberations sorely missed in the past. (Whether inflation targeting actually played a role in the achievement of more stable prices, as has occurred in many of the countries that have adopted this framework - but also in others that have not - is an empirical issue that lies beyond the scope of this paper.) 
But inflation targeting — at least in today's inherited monetary policymaking context — also serves two further objectives that are of more questionable import, and while seemingly contradictory, the two are ultimately related: By forcing participants in the monetary policy debate to conduct the discussion in a vocabulary pertaining solely to inflation, inflation targeting fosters over time the atrophication of concerns for real outcomes. In the meanwhile, inflation targeting hides from public view whatever concerns for real outcomes policymakers do maintain. Both objectives are understandable. Whether either is desirable on economic grounds is an open question. Neither is very consistent with the role of monetary policy in a democracy. Hence there is work remaining to do, and it is serious work at that. Charles Goodhart would be disappointed if it were otherwise. 


\section{$\underline{\text { References }}$}

Ahmed, Shaghil, and John H. Rogers. 2000. "Inflation and the Great Ratios: Long Run Evidence from the U.S." Journal of Monetary Economics, 45 (February), 3-35.

Blanchard, Olivier J., and Lawrence H. Summers. 1986. "Hysteresis and European Unemployment." NBER Macroeconomics Annual, 1, 15-78.

Broaddus, J. Alfred, Jr. 2001. "Transparency in the Practice of Monetary Policy." Federal Reserve Bank of Richmond, Economic Quarterly, 87 (Summer), 1-9.

Calvo, Guillermo A. 1983. "Staggered Contracts in a Utility-Maximizing Framework." Journal of Monetary Economics, 12 (September), 383-398.

Clarida, Richard, Jordi Gali, and Mark Gertler. 1999. "The Science of Monetary Policy: A New Keynesian Perspective." Journal of Economic Literature, 37 (December), 1661-1707.

Debelle, Guy, and Stanley Fischer. 1994. "How Independent Should a Central Bank Be?" Fuhrer (ed.), Goals, Guidelines, and Constraints Facing Monetary Policy. Boston: Federal Reserve Bank of Boston.

Goodfriend, Marvin, and Robert King. 2001. "The Case for Price Stability." The First ECB Central Banking Conference, Why Price Stability? Frankfurt: European Central Bank.

Hume, David. 1741 (1985). "Of the Parties of Great Britain.” Essays: Moral, Political, and Literary (Miller, ed.). Indianapolis: Liberty Fund.

King, Mervyn. 1997. "Changes in UK Monetary Policy: Rules and Discretion in Practice." Journal of Monetary Economics, 39 (June), 81-97.

King, Mervyn. 2000. "Address to the Joint Luncheon of the American Economic Association and the American Finance Association." Unpublished: Bank of England.

King, Robert G, and Mark W. Watson. 1994. "The Post-War U.S. Phillips Curve: A Revisionist Econometric History." Carnegie-Rochester Conference Series on Public Policy, 41 (December), 157-219.

Lasch, Christopher. 1991. The True and Only Heaven: Progress and Its Critics. New York: Norton.

Matsushita, Yasuo. 1996. "The Role of Monetary Policy." Speech to the Research Institute of Japan (November 6). Bank of Japan web site: www.boj.or.jp/en/press/koen004.htm. 
Roberts, John M. 1995. "New Keynesian Economics and the Phillips Curve." Journal of Money, Credit and Banking, 27 (November), 975-984.

Rotemberg, Julio J. 1982. "Sticky Prices in the United States." Journal of Political Economy, 60 (November), 1187-1211.

Solow, Robert M. 1998. "How Cautious Must the Fed Be?" Solow and Taylor, Inflation, Unemployment and Monetary Policy. Cambridge: MIT Press.

Svennson, Lars E.O. 1997. "Inflation Forecast Targeting: Implementing and Monitoring Inflation Targets." European Economic Review, 41 (June), 1111-1146.

Taylor, John B. 1979. "Staggered Contracts in a Macro Model." American Economic Review, 69 (May), 108-113.

Welteke, Ernst. 2001. Remarks quoted in The New York Times (August 30), W1.

Woodford, Michael. 1994. "Nonstandard Indicators for Monetary Policy: Can Their Usefulness Be Judged from Forecasting Regressions?" Mankiw (ed.), Monetary Policy. Chicago: University of Chicago Press. 